\title{
Article
}

\section{The Influencing Factors for Volume Stability of Ladle Slag}

\author{
Tung-Hsuan Lu ${ }^{1}$, Ying-Liang Chen ${ }^{2}{ }^{\mathbb{O}}$, Hong-Paul Wang ${ }^{1, *}$ and Juu-En Chang ${ }^{1, *}$ \\ 1 Department of Environmental Engineering, National Cheng Kung University, No. 1, Daxue Rd. East Dist., \\ Tainan City 701401, Taiwan; P58021029@ncku.edu.tw \\ 2 Department of Resources Engineering, National Cheng Kung University, No. 1, Daxue Rd. East Dist., \\ Tainan City 701401, Taiwan; roy.yl.chen@gmail.com \\ * Correspondence: wanghp@mail.ncku.edu.tw (H.-P.W.); juuen@mail.ncku.edu.tw (J.-E.C.); \\ Tel.: +886-6-2757575 (ext. 65850\#32) (H.-P.W.); +886-6-2757575 (ext. 65824); Fax: +886-6-2752790 (J.-E.C.)
}

check for updates

Citation: Lu, T.-H.; Chen, Y.-L.; Wang, H.-P.; Chang, J.-E. The Influencing Factors for Volume Stability of Ladle Slag. Processes 2022, 10, 92. https:// doi.org/10.3390/pr10010092

Academic Editor: Andrea Petrella

Received: 1 November 2021 Accepted: 29 December 2021 Published: 3 January 2022

Publisher's Note: MDPI stays neutral with regard to jurisdictional claims in published maps and institutional affiliations.

Copyright: (C) 2022 by the authors. Licensee MDPI, Basel, Switzerland. This article is an open access article distributed under the terms and conditions of the Creative Commons Attribution (CC BY) license (https:// creativecommons.org/licenses/by/ $4.0 /)$.

\begin{abstract}
The purpose of this study was to investigate the mechanism causing the unsoundness of ladle slag. Calcination temperature may have an impact on the level of reactivity of $\mathrm{f}-\mathrm{CaO}$. When $\mathrm{CaO}$ was produced at a higher temperature, the reactivity of $\mathrm{CaO}$ was lower. For example, dead burnt $\mathrm{CaO}(\mathrm{DCaO})$ was produced at higher temperatures than light burnt $\mathrm{CaO}(\mathrm{LCaO})$; therefore, $\mathrm{DCaO}$ had less reactivity than $\mathrm{LCaO}$. In a hydration test, $\mathrm{DCaO}\left(1500{ }^{\circ} \mathrm{C}\right)$ showed 62 times lower reactivity than $\mathrm{LCaO}\left(900{ }^{\circ} \mathrm{C}\right)$, which meant that $\mathrm{DCaO}$ would result in the delay of hydration of $\mathrm{CaO}$ easily. Additionally, $\mathrm{DCaO}$ would cause unsoundness more easily than $\mathrm{LCaO}$ when adding the same number of cementitious materials. For this reason, using ASTM C114-18 (Standard Test Methods for Chemical Analysis of Hydraulic Cement) to quantify DCaO content may underestimate $\mathrm{DCaO}$ content by up to $20 \%$. Conversely, this method was more suitable for $\mathrm{f}-\mathrm{CaO}$ since it had high reactivity. Moreover, this study demonstrated that ladle slag would cause unsoundness when added into the cementitious material because it was produced from a higher temperature process (over $1500^{\circ} \mathrm{C}$ ), which generates the DCaO. Therefore, when reusing ladle slag, the problem of low reactivity of $\mathrm{DCaO}$ should be considered.
\end{abstract}

Keywords: $\mathrm{CaO}$ reactivity; calcination temperatures; volume stability; ladle slag

\section{Introduction}

Steel slag has high potential for use as a substitute for cement in civil engineering projects such as construction and road-building engineering [1-5]. However, the application of steel slag, especially ladle slag, in engineering has been limited on account of the presence of free $\mathrm{CaO}(\mathrm{f}-\mathrm{CaO})$ and free $\mathrm{MgO}(\mathrm{f}-\mathrm{MgO})$. Presence of these results in volume expansion or unsoundness [6-9] because the water in the cement paste reacts with the $\mathrm{f}-\mathrm{CaO}$ and $\mathrm{f}-\mathrm{MgO}$. After reacting, these then transform into $\mathrm{Ca}(\mathrm{OH})_{2}$ and $\mathrm{Mg}(\mathrm{OH})_{2}$, which lead to popout on the paste surface, potentially reducing the strength of the concrete and compromising the building structure [10-14]. (For example, the volume would expand 89\% when f-CaO transforms into $\mathrm{Ca}(\mathrm{OH})_{2}$.) Wang et al. [10] reported free $\mathrm{CaO}$ as a significant contributor to the volume expansion of steel slag. At present, one of the methods of assessing unsoundness in cement paste is measuring the content of $\mathrm{f}-\mathrm{CaO}$, where $\mathrm{f}-\mathrm{CaO}$ refers to the unreacted $\mathrm{CaO}$ existing in steel slag [15]. However, using the amount of $\mathrm{f}-\mathrm{CaO}$ as a reference may make it difficult to measure the extent of the soundness in the cement paste accurately. Suito et al. [16] indicated that adding steelmaking slag with $1 \mathrm{wt} \%$ of $\mathrm{f}-\mathrm{CaO}$ in cement paste would cause unsoundness. On the other hand, previous studies [15,17] indicated that adding fly ash with $\mathrm{f}-\mathrm{CaO}$ content 0 to $3.25 \mathrm{wt}$.\% in cement would retain its soundness as well. Moreover, some studies even showed $\mathrm{f}-\mathrm{CaO}$ in fly ash could enhance compressive strength $[15,18]$. These studies demonstrated opposite results: a higher $\mathrm{f}-\mathrm{CaO}$ content maintained soundness and increased compressive strength; however, a lower content of $\mathrm{f}-\mathrm{CaO}$ leads to unsoundness. Little is known about this inconsistency; therefore, it is valuable to explore. 
Previous papers $[19,20]$ have reported different perspectives on the expansion of $\mathrm{f}-\mathrm{CaO}$ and $\mathrm{f}-\mathrm{MgO}$. They have indicated that only the overburnt form of $\mathrm{f}-\mathrm{CaO}$ and $\mathrm{f}-\mathrm{MgO}$ would lead to volumetric expansion. These types of overburnt $\mathrm{CaO}$ and $\mathrm{MgO}$ were produced under high sintering temperatures in slag refining and often enclosed within other clinker phases or metal oxide phases in slag. The crystallite size of overburnt $\mathrm{CaO}$ and $\mathrm{MgO}$ becomes significant. Their reactivity was very low, and the hydration rate was slow under ambient temperature. According to a previous paper [21], there are different grades of calcinated $\mathrm{CaO}$ depending on the calcining temperature of calcite $\left(\mathrm{CaCO}_{3}\right)$. As suggested earlier, one may deduce that different calcination temperatures will yield different grades of $\mathrm{CaO}$ and cause different expansion behavior.

This research aims to investigate the effect of the calcination temperatures of $\mathrm{CaO}$ on the soundness of cementitious material. With different calcinating temperatures, $\mathrm{CaO}$ can be classified into light and dead burnt states. The study will measure the reactivity of DCaO and $\mathrm{LCaO}$ to explain why the different sources of $\mathrm{f}-\mathrm{CaO}$ will cause different hydration behavior.

\section{Materials and Methods}

\subsection{Materials}

In this study, two types of $\mathrm{CaO}$ (light burnt or dead burnt) were prepared at different calcining temperatures, and the SEM results are shown in Figure 1. Analytical grade $\mathrm{LCaO}$ was employed, and $\mathrm{DCaO}$ was prepared by calcining the $\mathrm{LCaO}$ at $1500{ }^{\circ} \mathrm{C}$ in a calcination chamber. All types of $\mathrm{CaO}$ were ground beyond $150 \mu \mathrm{m}$ (No. 100 mesh, USA standard testing sieve). The characteristics of $\mathrm{CaO}$ with different levels of calcination and cement paste were determined using mineralogy analysis. Figure 2 shows the XRD pattern of two types of $\mathrm{CaO}$. $\mathrm{LCaO}$ and $\mathrm{DCaO}$ have the same characteristic peaks with two thetas; however, there is a difference in peak intensity. DCaO had two to three times higher intensity compared with LCaO. Additionally, the ladle slag and fly ash used in this study were from Dragon Steel, Taiwan, and Linkou Thermal Power Plant, Taiwan Power Company, respectively. The chemical compositions of ladle slag and fly ash are shown in Table 1.
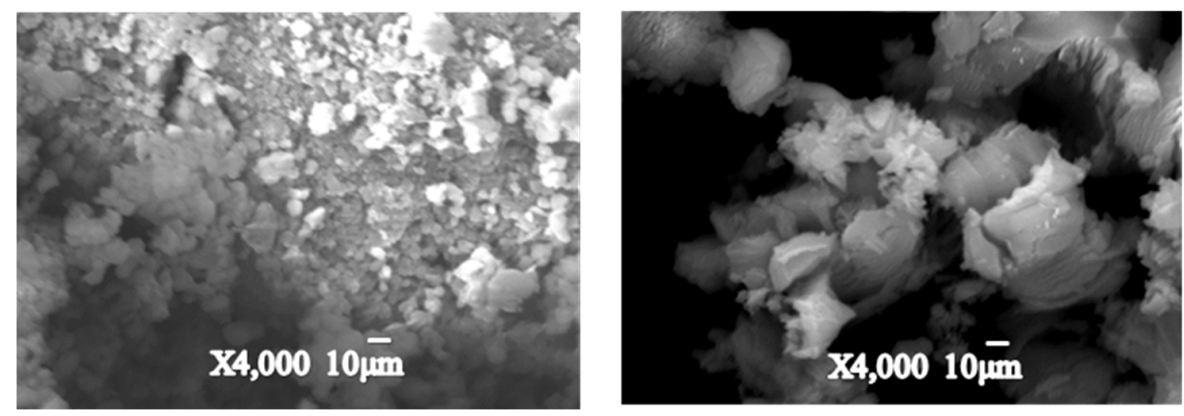

Figure 1. SEM results of light-burnt $\mathrm{CaO}$ and dead-brunt $\mathrm{CaO}$.

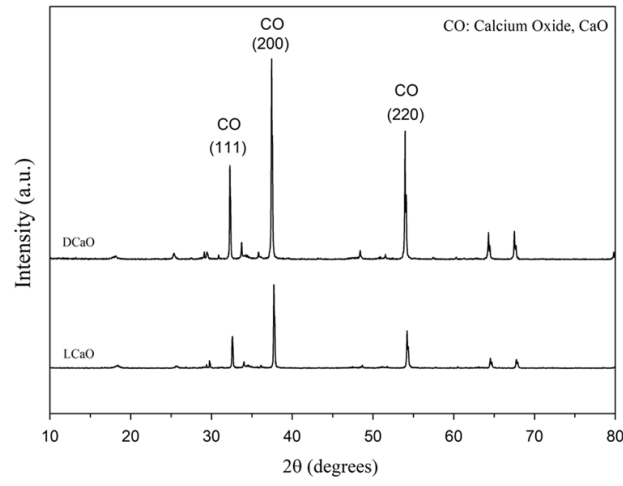

Figure 2. XRD pattern of light-burnt $\mathrm{CaO}$ and dead-burnt $\mathrm{CaO}$. 
Table 1. Chemical compositions of ladle slag and fly ash.

\begin{tabular}{|c|c|c|c|c|c|}
\hline \multicolumn{3}{|c|}{ Ladle Slag } & \multicolumn{3}{|c|}{ Fly Ash } \\
\hline \multirow{5}{*}{$\begin{array}{c}\text { Elements } \\
\text { (wt.\%) }\end{array}$} & $\mathrm{Ca}$ & 29.25 & \multirow{7}{*}{$\begin{array}{c}\text { Elements } \\
(\mathrm{wt} . \%)\end{array}$} & $\mathrm{Ca}$ & 14.94 \\
\hline & $\mathrm{Al}$ & 2.24 & & $\mathrm{Si}$ & 17.82 \\
\hline & $\mathrm{Mg}$ & 9.93 & & $\mathrm{Al}$ & 8.11 \\
\hline & $\mathrm{Fe}$ & 2.83 & & $\mathrm{Mg}$ & 1.38 \\
\hline & Si & 4.77 & & $\mathrm{Fe}$ & 4.23 \\
\hline \multirow{8}{*}{$\begin{array}{l}\text { Heavy } \\
\text { Metals } \\
\text { (mg/kg) }\end{array}$} & \multirow{8}{*}{$\mathrm{Mn}$} & \multirow{8}{*}{7435} & & $\mathrm{Na}$ & 0.52 \\
\hline & & & & K & 0.62 \\
\hline & & & \multirow{6}{*}{$\begin{array}{l}\text { Heavy } \\
\text { Metals } \\
(\mathrm{mg} / \mathrm{kg})\end{array}$} & $\mathrm{Mn}$ & 406 \\
\hline & & & & $\mathrm{Pb}$ & 123 \\
\hline & & & & $\mathrm{Cu}$ & 56 \\
\hline & & & & As & 500 \\
\hline & & & & $\mathrm{Ti}$ & 3633 \\
\hline & & & & $\mathrm{Ba}$ & 673 \\
\hline
\end{tabular}

\subsection{Material Testing and Analyses}

In the mineralogy analysis, an X-ray diffractometer (D8 Advance, Bruker, MA, USA) was used to identify the mineralogy phases of $\mathrm{CaO}$ and blended cement pastes. Samples were homogenized, ground until they were less than $75 \mu \mathrm{m}$ (No. 200 mesh, USA standard testing sieve), and pressed into a flat disc. All XRD analyses were carried out with the following parameters: (1) scanning range of $10^{\circ}-80^{\circ}(2 \theta)$, (2) a step size of $0.03^{\circ}$, and (3) a data collection rate of $2 \mathrm{~s}$ per step.

To measure the reactivity of different types of $\mathrm{CaO}$, a hydration test was conducted. The hydration test was carried out by reacting $1 \mathrm{~g}$ of different types of calcinated $\mathrm{CaO}$ with $50 \mathrm{~mL}$ of water at $50{ }^{\circ} \mathrm{C}$. Thermogravimetric analysis was then conducted to measure the amount of $\mathrm{CaO}$ transforming into $\mathrm{Ca}(\mathrm{OH})_{2}$ [22].

A thermogravimetric analyzer (DSC-TGA, TA Instrument, Taipei City, Taiwan) was used to investigate the thermal characteristics of the $\mathrm{CaO}$ hydration products and blended cement pastes. The samples were first homogenized and ground into a fine powder, 40-50 mg of which was loaded into an alumina crucible for analysis. The furnace temperature was programmed to rise from ambient temperature to $1000{ }^{\circ} \mathrm{C}$ by the heating rate of $20^{\circ} \mathrm{C} / \mathrm{min}$ under an air flow rate of $100 \mathrm{~mL} / \mathrm{min}$. A weight loss was observed at approximately $400{ }^{\circ} \mathrm{C}$ to $500{ }^{\circ} \mathrm{C}$. This resulted from the evolution of hydroxyl water in this temperature interval, where $\mathrm{Ca}(\mathrm{OH})_{2}$ dehydroxylated. Therefore, the percentage of $\mathrm{CaO}$ transformed into $\mathrm{Ca}(\mathrm{OH})_{2}$ can be calculated using the thermogravimetric analyzer and measured based on weight loss changes caused by dihydroxylation [23].

The $\mathrm{f}-\mathrm{CaO}$ content analysis was determined according to ASTM C114-18 [24]. A complexometric titration method was conducted by adding $1 \mathrm{~g}$ of the sample to $60 \mathrm{~mL}$ of ethanol-glycerol solution $\left(\mathrm{C}_{5} \mathrm{H}_{14} \mathrm{O}_{4}\right)$ and strontium nitrate $\left(\mathrm{Sr}\left(\mathrm{NO}_{3}\right)_{2}\right)$ under digestion in a hot water bath for $20 \mathrm{~min}$.

EN-450 [25] regulates that the amount of free lime content shall not be higher than $1 \%$ in fly ash or up to $2.5 \%$ if autoclave expansion test results are satisfactory. Therefore, in this study, the double standard amount of $\mathrm{CaO}$ was added to amplify the different behavior of two different types of $\mathrm{CaO}$. Different types of $\mathrm{CaO}$ were employed separately to replace $5 \mathrm{wt} . \%$ of Portland cement.

An autoclave expansion test (ASTM C151/C151M [26]) was employed to determine the volumetric stability of the specimens mixed with $\mathrm{LCaO}, \mathrm{DCaO}$, and ladle slag, respectively. In this test, the hardened paste specimens were made into a mortar bar $(25 \times 25 \times 285 \mathrm{~mm})$, cured in a moist closet for $24 \mathrm{~h}$, and autoclaved at $2 \pm 0.07 \mathrm{MPa}$ for $3 \mathrm{~h}$. Changes in length were recorded afterward. 


\section{Results and Discussion}

\subsection{The Reactivity of Calcinated $\mathrm{CaO}$}

The reactivity of the calcinated $\mathrm{CaO}$ was discussed in this paper to examine the relationships among its physical characteristics, which affect its chemical reactivity. First, a hydration test was used to establish the reactivity of $\mathrm{CaO}$ at different calcination temperatures. $\mathrm{LCaO}$ and $\mathrm{DCaO}$ were assessed in the hydration test under $0.5,1.5,3,5,15$, and $80 \mathrm{~min} ; 5,15,30,40,60$, and $80 \mathrm{~min}$, respectively. The stoichiometric $\mathrm{CaO}$ contents calculated from the amount of $\mathrm{Ca}(\mathrm{OH})_{2}$ in the $\mathrm{LCaO}$ and $\mathrm{DCaO}$ as tested from the thermogravimetric analysis are revealed in Table 2. Figure 3 illustrates the thermogravimetric analysis results showing the percentage of the reacted $\mathrm{CaO}$ (wt.\%) over time. As shown in Figure 3, the reactivity of $\mathrm{LCaO}$ was extremely fast. At $0.5 \mathrm{~min}, 39.64 \mathrm{wt} . \%$ of the $\mathrm{CaO}$ had already reacted and transformed into $\mathrm{Ca}(\mathrm{OH})_{2}$; after $0.5 \mathrm{~min}$, the slope was gentler, indicating that the reaction rate had slowed down. The reacted $\mathrm{CaO}$ remained constant between 5 and $80 \mathrm{~min}$, corresponding to $70 \mathrm{wt} . \%$ of $\mathrm{CaO}$ reacted. The reaction rate of $\mathrm{DCaO}$ was much slower than that of the $\mathrm{LCaO}$, with the amount of $\mathrm{CaO}$ constantly increasing from 0 to $40 \mathrm{~min}$. The reaction rate remained constant when the reaction time was $40 \mathrm{~min}$ or above. In the case of the $\mathrm{DCaO}$, only $50 \mathrm{wt} . \%$ of the $\mathrm{CaO}$ was reacted. In addition, it was discovered that the fitted regression line was close to a first-order reaction. Figure 3 illustrates that the initial hydration rate of the $\mathrm{LCaO}$ and $\mathrm{DCaO}$ by fitting into the first-order reaction, and the rate constant $(\mathrm{k})$ of the $\mathrm{LCaO}$ and $\mathrm{DCaO}$ was 2.49 and 0.04 , respectively (The rate constant of the $\mathrm{LCaO}$ was approximately 62 times greater than that of the $\mathrm{DCaO}$ ).

Table 2. Hydration test of different calcinated temperature $\mathrm{CaO}$.

\begin{tabular}{|c|c|c|c|c|c|}
\hline \multicolumn{3}{|c|}{$\mathrm{LCaO}$} & \multicolumn{3}{|c|}{$\mathrm{DCaO}$} \\
\hline Time (min) & $\begin{array}{c}\mathrm{Ca}(\mathrm{OH})_{2} \\
\text { (wt. } \%)\end{array}$ & $\begin{array}{c}\mathrm{CaO} \\
\text { (wt.\%) }\end{array}$ & Time (min) & $\begin{array}{c}\mathrm{Ca}(\mathrm{OH})_{2} \\
(\text { wt. } \%)\end{array}$ & $\begin{array}{c}\mathrm{CaO} \\
(w \mathrm{t} . \%)\end{array}$ \\
\hline 0.5 & 52.38 & 39.64 & 5 & 10.44 & 7.90 \\
\hline 1.5 & 59.04 & 44.68 & 15 & 25.94 & 19.63 \\
\hline 3 & 64.63 & 48.91 & 30 & 41.65 & 31.51 \\
\hline 5 & 68.00 & 51.46 & 40 & 53.24 & 40.29 \\
\hline 15 & 70.09 & 53.04 & 60 & 53.61 & 40.57 \\
\hline 80 & 70.34 & 53.23 & 80 & 54.5 & 41.13 \\
\hline
\end{tabular}

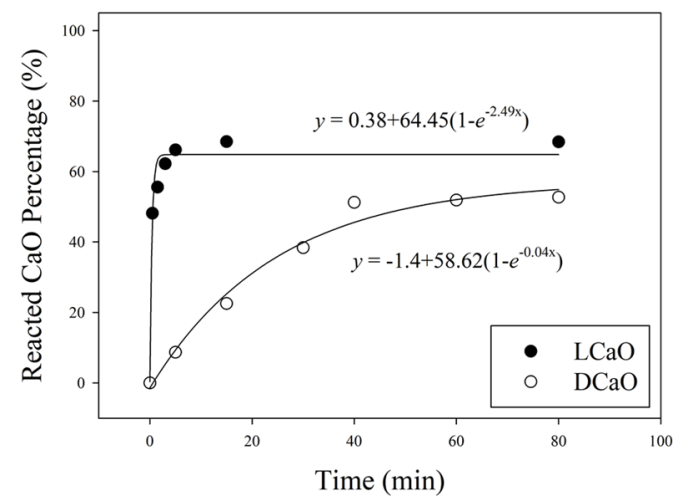

Figure 3. Effect of different calcinated temperature $\mathrm{CaO}$ on the hydration reaction curve.

Moreover, the grain sizes of $\mathrm{LCaO}$ and $\mathrm{DCaO}$ are $87.19 \mathrm{~nm}$ and $103.93 \mathrm{~nm}$, respectively. A previous study stated that the reactivity of $\mathrm{CaO}$ would decrease with the increase in crystallite size and the decrease in the specific surface area when the calcination temperature is increased [27]. Berent et al. [28] indicated that the crystallite size and the crystallinity of the final product would increase with the calcination temperature. Mohamad et al. [29] also reported the same result: a high calcination temperature made a bigger crystallite size. Wang et al. [10] indicated that due to the high calcining temperature, the structure of free 
$\mathrm{CaO}$ became denser and decreased the hydration reactivity for free $\mathrm{CaO}$. Therefore, the calcination temperature might significantly affect the $\mathrm{CaO}$ reactivity required to transform into $\mathrm{Ca}(\mathrm{OH})_{2}$. Another paper [21] mentioned that, for $\mathrm{CaO}$, the apparent density increased, and the porosity decreased with the increasing calcination temperature of $\mathrm{CaO}$, hence leading to a decrease in the reaction interface area and low hydration reactivity. To summarize, $\mathrm{DCaO}$ has a lower reactivity than $\mathrm{LCaO}$ due to the high calcination temperature.

\subsection{Different Types of Calcination CaO on Volume Stability}

The $\mathrm{f}-\mathrm{CaO}$ (unreacted $\mathrm{CaO}$ ) content was one of the indexes used to evaluate whether the cementitious material was stable. However, past findings have concluded that $\mathrm{f}-\mathrm{CaO}$ content might not be a reliable index. Based on the mentioned results, the stability might be related to the calcination temperature. To determine whether the $\mathrm{CaO}$ calcination temperature is also a factor of soundness, $\mathrm{CaO}$ was calcinated under two different temperatures, one was $900{ }^{\circ} \mathrm{C}(\mathrm{LCaO})$, and the other was $1500{ }^{\circ} \mathrm{C}(\mathrm{DCaO})$; and two kinds of $\mathrm{CaO}$ were added $5 \mathrm{wt} \%$ to OPC (in this study, OPC-LCaO, OPC-DCaO). The f-CaO content was tested according to the standard ASTM C114-18 [24] method. The results are shown in Table 3. The average f-CaO content of OPC, $\mathrm{LCaO}$, and $\mathrm{DCaO}$ was 1.36 wt. $\%, 6.33$ wt.\%, and $5.29 \mathrm{wt} . \%$, respectively. After subtracting the background $\mathrm{f}-\mathrm{CaO}$ content in control, the $\mathrm{f}-\mathrm{CaO}$ content in the light and dead burnt state was 4.97 and $3.93 \mathrm{wt}$ \%, respectively. As $5 \mathrm{wt} . \%$ of $\mathrm{LCaO}$ and $\mathrm{DCaO}$ were added, the proportion of the not-detected $\mathrm{f}-\mathrm{CaO}$ in the f-CaO content test was 0.03 wt. $\%$ and 1.07 wt. $\%$, respectively. The recovery rate of $\mathrm{LCaO}$ and $\mathrm{DCaO}$ was $101 \%$ and $80 \%$.

Table 3. Effect of different types of calcination $\mathrm{CaO}$ on measured $\mathrm{f}-\mathrm{CaO}$ content (under ASTM C114-18).

\begin{tabular}{cccc}
\hline $\begin{array}{c}\text { Type of Calcination } \\
\text { CaO }\end{array}$ & f-CaO in OPC(wt.\%) & $\begin{array}{c}\text { Measured } \\
\text { f-CaO(wt.\%) }\end{array}$ & Recovery Percentage \\
\hline OPC-LCaO & $1.63 \pm 0.03$ & $6.63 \pm 0.02$ & $101 \%$ \\
OPC-DCaO & $1.63 \pm 0.03$ & $5.29 \pm 0.02$ & $80 \%$ \\
\hline
\end{tabular}

OPC: ordinary Portland cement; Recovery rate: $\left(\mathrm{f}-\mathrm{CaO}_{\text {Measured }}-0.95^{*} \mathrm{f}-\mathrm{CaO}\right.$ OPC $) / \mathrm{CaO}$ added quantity; $\mathrm{CaO}$ added quantity $=5 \%$.

Table 4 demonstrates the change in the length of the OPC-LCaO and OPC-DCaO paste bar before and after the autoclave expansion test, in which the pure cement paste bar was taken as the control. The result revealed that the pure cement paste bar and OPC-LCaO were stable $(0.8 \%)$ after autoclaving, and the increased length was 0.11 and 0.07, respectively. However, OPC-DCaO was severely cracked and unmeasurable. The result disclosed that high $\mathrm{f}-\mathrm{CaO}$ was detected in the OPC-LCaO, but it maintained stability. Nevertheless, lower f-CaO was detected in the OPC-DCaO, which suffered cracks. It can be seen in Table 4 that most of the $\mathrm{LCaO}$ were converted into $\mathrm{Ca}(\mathrm{OH})_{2}$, while $\mathrm{DCaO}$ was only partly converted. Since most of the $\mathrm{CaO}$ in OPC-LCaO was converted into $\mathrm{Ca}(\mathrm{OH})_{2}$ before the autoclave expansion test, $\mathrm{Ca}(\mathrm{OH})_{2}$ did not increase much after the test. Therefore, it remained stable. Additionally, $\mathrm{CaO}$ in the OPC-DCaO was partially converted to $\mathrm{Ca}(\mathrm{OH})_{2}$ before the autoclave expansion test because of its low reactivity. On that account, after the autoclave expansion test, $\mathrm{CaO}$ was converted into $\mathrm{Ca}(\mathrm{OH})_{2}$, so the amount of $\mathrm{Ca}(\mathrm{OH})_{2}$ increased significantly, ultimately resulting in unsoundness. The $\mathrm{f}-\mathrm{CaO}$ content test only measured the amount of $\mathrm{CaO}$ that could quickly take part in the hydration reaction. In other words, it only revealed the $\mathrm{CaO}$ with relatively high reactivity. The $\mathrm{CaO}$ with lower reactivity that did not contribute to the reaction was the undetected $\mathrm{CaO}$. This result demonstrates that the amount of $\mathrm{f}-\mathrm{CaO}$ might not be the only factor in volume stability. The type of $\mathrm{f}-\mathrm{CaO}$ was also one of the factors that would lead to soundness problems, which was similar to the results in the literature. A previous study [15] illustrated that fly ash, a by-product from the coal combustion process, containing around $1.98 \mathrm{wt} \% \mathrm{o}$ of $\mathrm{f}-\mathrm{CaO}$ could maintain its soundness. On the other hand, another study [16] on this topic indicated that if basic-oxygen-furnace slag (BOFS) contains about $1 \mathrm{wt} \%$ of free lime, it disintegrates. 
These two studies also displayed that $\mathrm{f}-\mathrm{CaO}$ content should not be the only standard of volume stability. In general, the temperature of steelmaking is higher than coal combustion. Therefore, the reactivity of $\mathrm{f}-\mathrm{CaO}$ resulting from BOFS and fly ash might be different and leads to different autoclave expansion test results. These two studies' results are similar to those in Table 4: CaO produced under high temperature quickly causes unsoundness problems, and the volumetric stability is also related to the type of $\mathrm{f}-\mathrm{CaO}$.

Table 4. $\mathrm{Ca}(\mathrm{OH})_{2}$ content $(\%)$ before and after autoclaving related to volume stability with different types of calcination $\mathrm{CaO}$.

\begin{tabular}{ccccc}
\hline \multirow{2}{*}{ Specimen } & Length Change (\%) & $\begin{array}{c}\text { Volume } \\
\text { Stability }\end{array}$ & $\begin{array}{c}\text { Ca(OH) } \\
\text { 2 Content (\%) }\end{array}$ \\
\cline { 4 - 5 } & & & $\begin{array}{c}\text { Before } \\
\text { Autoclaving }\end{array}$ & $\begin{array}{c}\text { After } \\
\text { Autoclaving }\end{array}$ \\
\hline OPC & $0.10 \pm 0.003$ & Sound & $10.77 \pm 1.03$ & $14.06 \pm 2.1$ \\
OPC-LCaO & $0.17 \pm 0.005$ & Sound & $14.1 \pm 1.33$ & $18.43 \pm 1.88$ \\
OPC-DCaO & Crack & Unsound & $13.36 \pm 1.27$ & $20.23 \pm 2.03$ \\
\hline
\end{tabular}

${ }^{1}$ Sound: $\leq 0.80 \%$; unsound: $>0.80 \%$.

An analysis of the mineralogy phase and the TG-DSC analysis of OPC-LCaO and OPC-DCaO before and after the autoclave expansion test were carried out to investigate the differences that lead to unsoundness. Figure 4 shows the XRD patterns of OPC, OPC$\mathrm{LCaO}$, and OPC-DCaO before autoclaving. The main discrepancy between OPC-LCaO and OPC-DCaO in the mineralogy analysis were listed as follows: (1) Before the autoclave expansion test, the XRD pattern of OPC-DCaO revealed a prominent $\mathrm{CaO}$ peak, although the phenomena were only slightly observed in the OPC-LCaO and OPC phases. (2) After the autoclave expansion test, the $\mathrm{CaO}$ peak disappeared in the OPC-DCaO, and the intensity of the $\mathrm{Ca}(\mathrm{OH})_{2}$ peak increased significantly. This result was attributed to the lower reactivity of the DCaO. Only part of the $\mathrm{DCaO}$ in the cement paste participated in the hydration reaction and hence contributed to an increase in $\mathrm{Ca}(\mathrm{OH})_{2}$ before the autoclave expansion test. In the case of OPC-LCaO, the peak of $\mathrm{CaO}$ was hardly observed. This was because most $\mathrm{LCaO}$ had taken part in cement hydration due to its high reactivity before the autoclave expansion test. The autoclaving process accelerated the hydration process under high temperature and high-pressure curing. In the XRD pattern of the OPC after autoclaving, there was an increase in the intensity of the $\mathrm{Ca}(\mathrm{OH})_{2}$ peak. It was found that the OPC$\mathrm{LCaO}$ was sound and continued to be almost the same after autoclaving, despite the slight increase in the intensity of the $\mathrm{Ca}(\mathrm{OH})_{2}$. The reason for the slight increase in $\mathrm{Ca}(\mathrm{OH})_{2}$ might be the amount of $\mathrm{LCaO}$ (a small portion), which did not take part in the hydration previously. As for the cement paste with $\mathrm{DCaO}$, which showed the result of unsoundness, there was a significant increase in the intensity of the $\mathrm{Ca}(\mathrm{OH})_{2}$ peak. The phenomena were led by the delay of DCaO hydration and thus caused volumetric expansion.
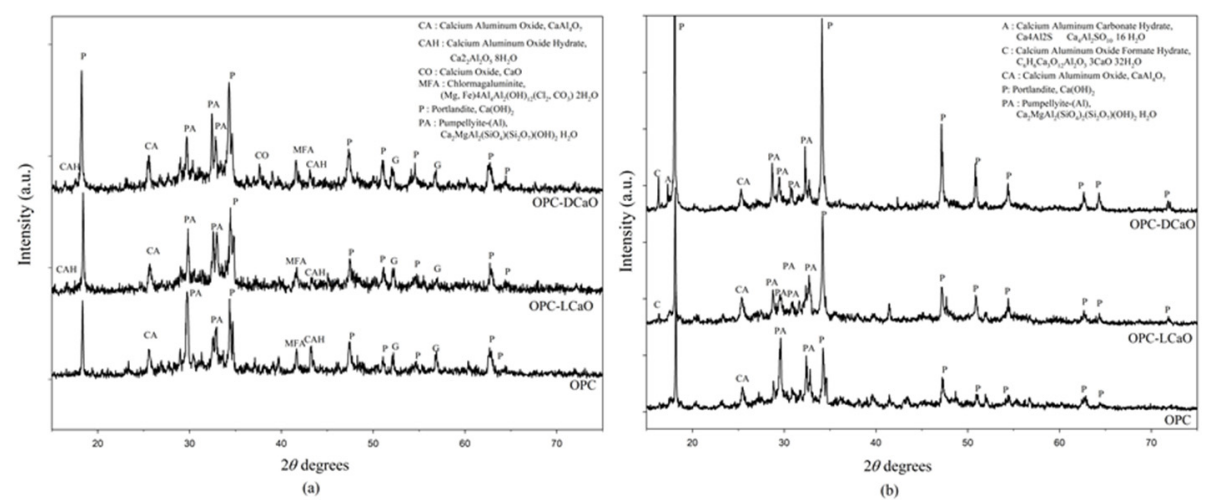

Figure 4. XRD patterns of OPC, OPC-LCaO and OPC-DCaO (a) before and (b) after the autoclave expansion test. 
Two common theories might explain the expansion mechanism of $\mathrm{CaO}$ as follows: (1) crystal growth pressure due to the growth of $\mathrm{Ca}(\mathrm{OH})_{2}$, and (2) swelling pressure due to water absorption by tiny crystals of $\mathrm{Ca}(\mathrm{OH})_{2}[30,31]$. In hardened cement, the increase in volume causes internal stresses, leading to severe damage and unsoundness if they exceed the structure's tensile strength. The increase in $\mathrm{Ca}(\mathrm{OH})_{2}$ was further verified by using thermogravimetric analysis. Table 4 shows the $\mathrm{Ca}(\mathrm{OH})_{2}$ content changes before and after the autoclave expansion test of the OPC, OPC-LCaO, and OPC-DCaO. In the case of OPC-LCaO, the change of $\mathrm{Ca}(\mathrm{OH})_{2}$ content before and after autoclaving was approximately 3.33 wt.\%, which was similar to the OPC. This result indicated that the added LCaO was almost completely hydrated during cement hydration before autoclaving. In the case of OPC-DCaO, the change of $\mathrm{Ca}(\mathrm{OH})_{2}$ content was $6.87 \mathrm{wt} . \%$, indicating a significant increase in $\mathrm{Ca}(\mathrm{OH})_{2}$. This implied that $\mathrm{DCaO}$ was still present before autoclaving and was hydrated during autoclaving, which may be due to the low reactivity of the DCaO and resulted in unsoundness in the hardened cement.

\subsection{Stability of Using Ladle Slag and Fly Ash}

The results presented that $\mathrm{f}-\mathrm{CaO}$ produced from the steelmaking process may be like $\mathrm{DCaO}$ since the steelmaking process is undertaken at approximately $1600{ }^{\circ} \mathrm{C}$. Therefore, the reactivity of $\mathrm{f}-\mathrm{CaO}$ resulting from the steelmaking process became slower. On the other hand, $\mathrm{f}-\mathrm{CaO}$ in the fly ash may be similar to $\mathrm{LCaO}$. In this section, the ladle slag from an electric arc furnace and fly ash were blended into the cement, sequentially, and compared with the result from the previous one. Figure 5 reveals the XRD pattern of ladle slag and fly ash. A sharp crystal phase of $\mathrm{Ca}(\mathrm{OH})_{2}$ and $\mathrm{Mg}(\mathrm{OH})_{2}$ can be found in the ladle slag, indicating that part of the $\mathrm{CaO}$ and $\mathrm{MgO}$ had been hydrated, and some $\mathrm{CaO}$ could still be found. Considering that the steelmaking temperature is about $1600{ }^{\circ} \mathrm{C}$, we deduce that $\mathrm{CaO}$ in the ladle slag is among $\mathrm{DCaO}$. Figure 5 illustrates that the main crystalline phases in fly ash were gismondine, quartz, and mullite. Halder et al. [32] also reported a similar result. They indicated that although there were $\mathrm{f}-\mathrm{CaO}$ crystalline phases in fly ash, the intensity of the $\mathrm{f}-\mathrm{CaO}$ peak was hardly observed due to the small amount.
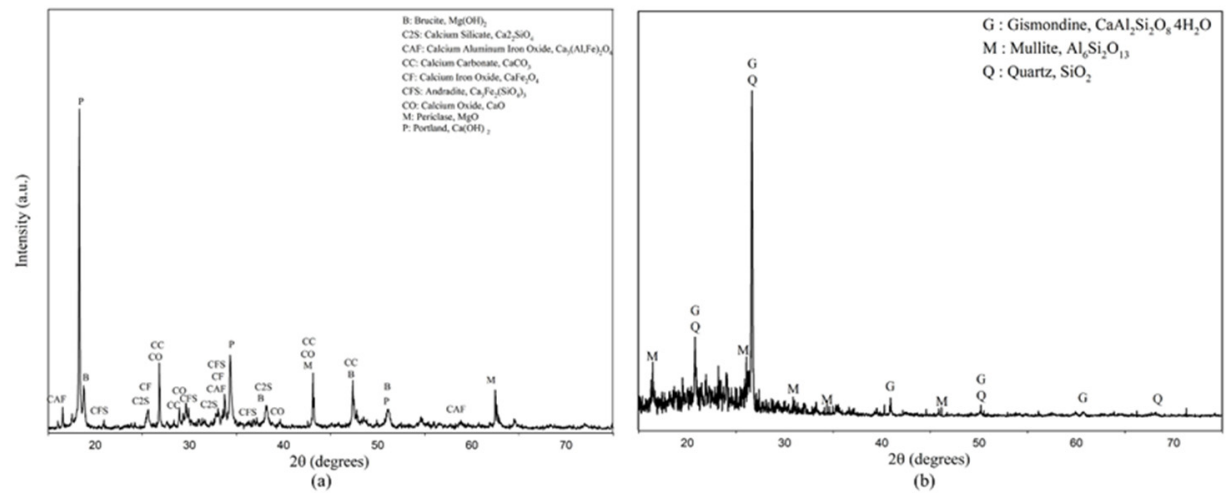

Figure 5. XRD pattern of (a) ladle slag and (b) fly ash.

In order to compare different hydration behaviors between different sources of $\mathrm{CaO}, \mathrm{a}$ paste bar was made, and the autoclave expansion test (ASTM C151/C151M) was applied. In the case of adding ladle slag, a paste bar $(25 \times 25 \times 285 \mathrm{~mm})$ was made of a cement paste with a $20 \mathrm{wt}$ \% replacement of ladle slag (in this research, OPLS). In the case of adding fly ash, a paste bar was made of a cement paste with a $35 \mathrm{wt} \%$ replacement of fly ash (in this research, OPFA). The $\mathrm{f}-\mathrm{CaO}$ content in OPLS was $1.36 \mathrm{wt} . \%$, and $\mathrm{f}-\mathrm{CaO}$ content in OPFA was $1.41 \mathrm{wt}$ \%. Figure 6 illustrates OPLS expanded and cracked results after the autoclave expansion test, indicating the ladle slag was an unsound cementitious material. Conversely, OPFA remained sound. The result matched with the previous studies [15-18], which revealed that ladle slag would cause unsoundness more easily than fly ash with the same f-CaO content. Figure 7 shows an XRD pattern of the paste bar before and after 
the autoclave expansion test, and Figure 8 illustrates an SEM of the paste with ladle slag. In the OPLS case, the $\mathrm{CaO}$ peak was found before the autoclave expansion test, but the $\mathrm{CaO}$ had vanished after the autoclave expansion test. At the same time, the intensity of the $\mathrm{Ca}(\mathrm{OH})_{2}$ peak increased after the autoclave expansion test. This might be caused by the $\mathrm{f}-\mathrm{CaO}$ converting into $\mathrm{Ca}(\mathrm{OH})_{2}$ during the autoclave expansion test; therefore, $\mathrm{Ca}(\mathrm{OH})_{2}$ increased. When $\mathrm{CaO}$ converted into $\mathrm{Ca}(\mathrm{OH})_{2}$, the volume expanded and caused the problem of unsoundness; in the case of OPFA, there was no $\mathrm{CaO}$ found before or after the autoclaving test. By applying the thermogravimetric analysis, one can also observe that there was 12.58 wt. $\%$ of $\mathrm{Ca}(\mathrm{OH})_{2}$ before the autoclave expansion test, and the amount of $\mathrm{Ca}(\mathrm{OH})_{2}$ rose to $23.05 \mathrm{wt} . \%$ after the autoclave expansion test in the OPLS, as shown in Table 5; thus, there was a more significant amount of $\mathrm{Ca}(\mathrm{OH})_{2}$ produced during the autoclave expansion test which consequently caused unsoundness. The result matched the previous experiment data; that is, high calcination temperature would delay the hydration reaction of $\mathrm{CaO}$ and easily cause cracking.

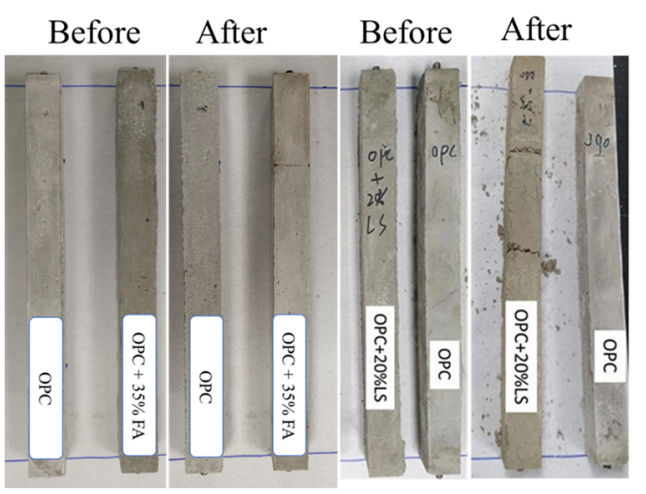

Figure 6. Cement pastes with ladle slag and with fly ash before and after the autoclave expansion test.
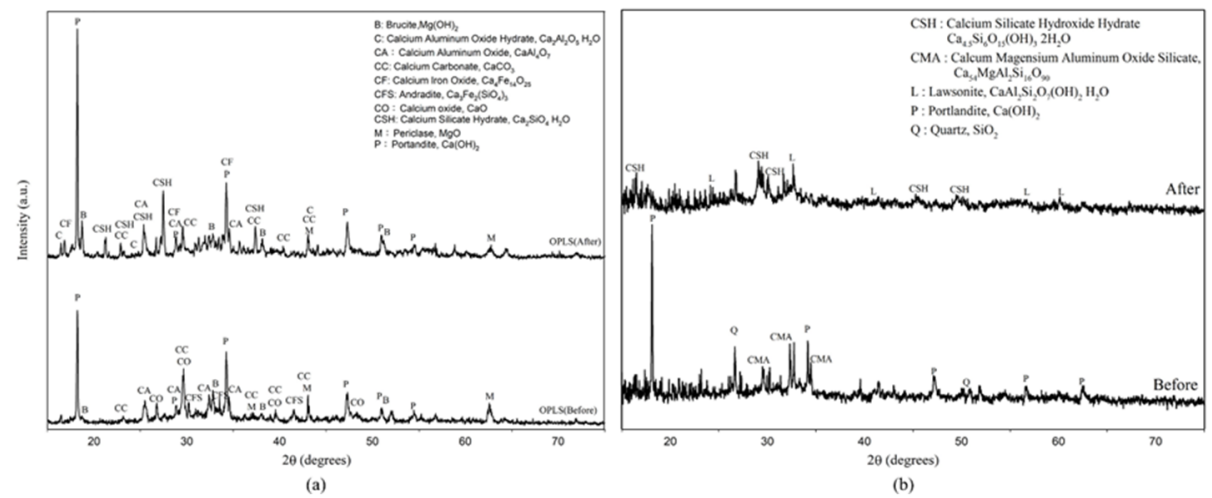

Figure 7. XRD patterns of cement paste with (a) ladle slag and (b) fly ash before and after the autoclave expansion test.

Table 5. $\mathrm{Ca}(\mathrm{OH})_{2}$ content (\%) before and after autoclaving related to volume stability with ladle slag and fly ash.

\begin{tabular}{ccccc}
\hline \multirow{2}{*}{ Specimen } & \multirow{2}{*}{$\begin{array}{c}\text { Length Change } \\
(\mathbf{\%})\end{array}$} & $\begin{array}{c}\text { Volume } \\
\text { Stability }\end{array}$ & & \multicolumn{2}{c}{$\mathrm{Ca}(\mathrm{OH})_{\mathbf{2}}$ Content (\%) } \\
\cline { 4 - 5 } & & & $\begin{array}{c}\text { Before } \\
\text { Autoclaving }\end{array}$ & $\begin{array}{c}\text { After } \\
\text { Autoclaving }\end{array}$ \\
\hline OPC & $0.10 \pm 0.003$ & Sound & $10.77 \pm 0.52$ & $14.06 \pm 1.1$ \\
OPLS & Crack & Unsound & $12.58 \pm 1.33$ & $23.05 \pm 1.88$ \\
OPFA & $0.02 \pm 0.005$ & Sound & $7.75 \pm 0.04$ & $7.99 \pm 0.07$ \\
\hline
\end{tabular}

${ }^{1}$ Sound: $\leq 0.80 \%$; unsound: $>0.80 \%$. 


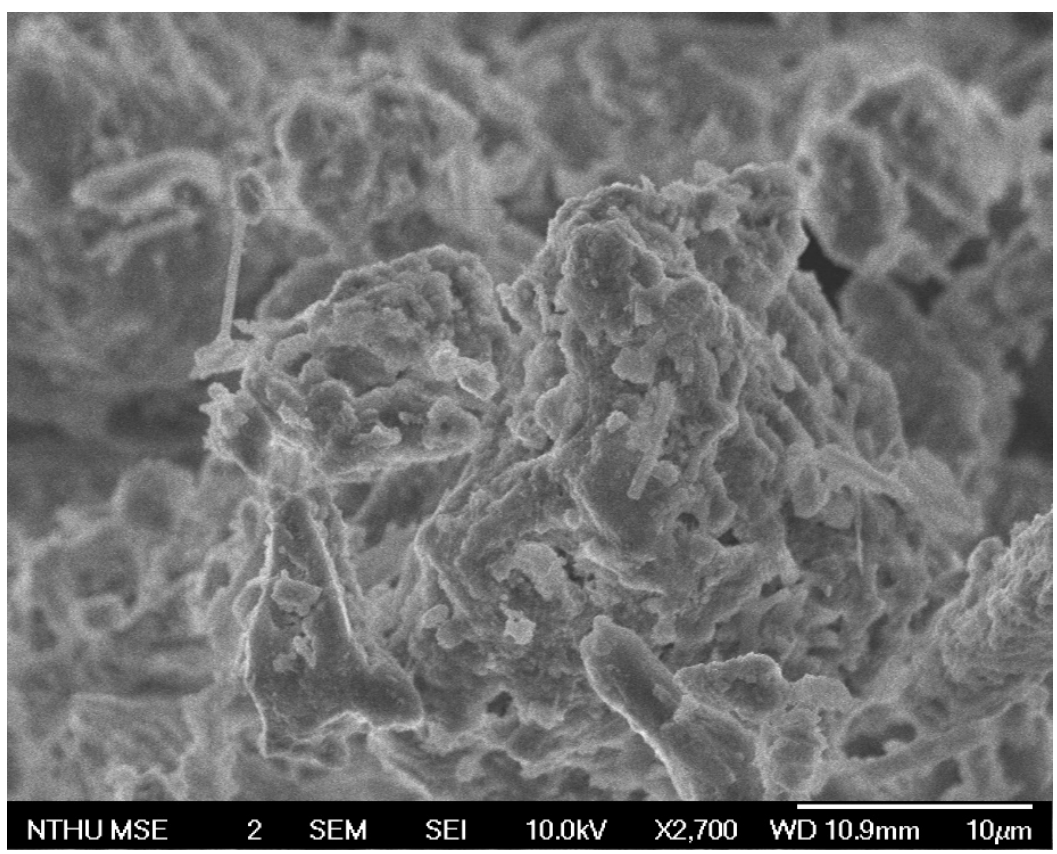

Figure 8. SEM of paste with ladle slag.

On the other hand, in the case of OPFA, the change to the $\mathrm{Ca}(\mathrm{OH})_{2}$ content was unobvious. Which meant $\mathrm{f}-\mathrm{CaO}$ in the fly ash had high reactivity, and it would thoroughly hydrate before the autoclave expansion test and maintain soundness. Wang et al. [33] also demonstrated the same result. Some papers showed that adding steelmaking slag with 1-2 wt.\% f-CaO content would cause volume instability [16,33]. Conversely, another study demonstrated that fly ash with 1.98 wt. $\%$ of $\mathrm{f}-\mathrm{CaO}$ when added to cement maintained soundness [15]. From the experiment data discussed and some previous studies, one can deduce that the content of $\mathrm{f}-\mathrm{CaO}$ might not be the only factor affecting volume stability; different calcination temperatures yield different grades of $\mathrm{CaO}$ and cause different expansion behavior. Through the findings on the results presented, $\mathrm{f}-\mathrm{CaO}$ resulting from the steelmaking process may be similar to that obtained using $\mathrm{DCaO}$ for the steelmaking process, as this is a high-temperature process. Therefore, the reactivity of $\mathrm{f}-\mathrm{CaO}$ in ladle slag may be lower. The results indicated that ladle slag might potentially lead to volumetric expansion in cementitious materials.

\section{Conclusions}

It may be stated from the above results that different calcination temperatures and sources of $\mathrm{CaO}$ affect soundness; thus, free- $\mathrm{CaO}(\mathrm{f}-\mathrm{CaO})$ is the major obstacle to reusing ladle slag. Therefore, understanding the hydration behavior of $\mathrm{f}-\mathrm{CaO}$ in the ladle slag is the main issue with the recovery of ladle slag.

The key results can be summarized as follows:

1. Ladle slag resulting from a high-temperature process might contain dead burnt $\mathrm{CaO}(\mathrm{DCaO})$. The presence of $\mathrm{DCaO}$ is the reason that re-using ladle slag causes unsoundness.

2. Calcination temperatures may lead to different reactivity of $\mathrm{CaO}$. $\mathrm{DCaO}\left(1500{ }^{\circ} \mathrm{C}\right)$ reaction rate is 62 times smaller than light burnt $\mathrm{CaO}\left(900^{\circ} \mathrm{C}\right)$. In other words, $\mathrm{DCaO}$ would take a longer time to react and is more difficult to hydrate.

3. $\mathrm{CaO}$ produced under high temperature quickly causes unsoundness problems, and volumetric stability is also related to the type of $\mathrm{f}-\mathrm{CaO}$.

4. Using ASTM C114-18 [24] to evaluate $\mathrm{f}-\mathrm{CaO}$ content might lead to underestimating up to $20 \%$ of $\mathrm{DCaO}$ compared to the actual quantity for its low hydration reactivity. On the other hand, evaluating $\mathrm{LCaO}$ content would not lead to this problem since it 
has high hydration reactivity. Therefore, ASTM C114-18 [24] might not be suitable for testing the $\mathrm{DCaO}$ content.

5. The presence of $\mathrm{f}-\mathrm{CaO}$ leads to the unsoundness of ladle slag. Therefore, understanding the discrepancy of $\mathrm{f}-\mathrm{CaO}$ may be the key to the recovery of ladle slag.

6. Since the $\mathrm{f}-\mathrm{CaO}$ content in ladle slag is mainly $\mathrm{DCaO}$ with low reactivity, it is hard to quantify and has a high potential to delay hydration and cause expansion. On that account, there is room for further investigation on the method of detecting the quantity of $\mathrm{DCaO}$ and enhancing $\mathrm{DCaO}$ reactivity in order to reuse ladle slag as a cementitious material.

7. The expansion problem could not be judged directly based on the content of ladle slag. It should be based on the content of free $\mathrm{CaO}$ and $\mathrm{MgO}$, and the content of free $\mathrm{CaO}$ and $\mathrm{MgO}$ should be below $2.5 \%$ and $1 \%$, respectively.

Author Contributions: Conceptualization, T.-H.L. and Y.-L.C.; methodology, T.-H.L., Y.-L.C. and J.-E.C.; validation, T.-H.L., Y.-L.C. and H.-P.W.; formal analysis, T.-H.L.; investigation, T.-H.L.; data curation, Y.-L.C. and H.-P.W.; writing-original draft preparation, T.-H.L.; writing-review and editing, T.-H.L.; visualization, T.-H.L.; supervision, J.-E.C.; project administration, T.-H.L. All authors have read and agreed to the published version of the manuscript.

Funding: This research was funded by the Ministry of Science and Technology, grant number 107-2221-E-006-010.

Institutional Review Board Statement: Not applicable.

Informed Consent Statement: Not applicable.

Data Availability Statement: Not applicable.

Acknowledgments: The authors gratefully acknowledge the help of the laboratory and the Ministry of Science and Technology, Taiwan for its financial support of this study (contract number: 107-2221E-006-010).

Conflicts of Interest: The authors declare no conflict of interest.

\section{References}

1. Neville, A.M.; Brooks, J.J. Concrete Technology; Longman Scientific \& Technical: London, UK, 1987.

2. Neville, A.M. Properties of Concrete; Longman: London, UK, 1995.

3. Geiseler, J. Slag-approved materials for a better future. In Proceedings of the International Symposium on the Utilization of Metallurgical Slag (ISUS 99), Beijing, China, 16-19 November 1999.

4. Alizadeh, R.; Chini, M.; Ghods, P.; Hoseini, M.; Montazer, S.; Shekarchi, M. Utilization of Electric Arc Furnace Slag as Aggregates in Concrete-Environmental Issue. In Proceedings of the 6th CANMET/ACI International Conference on Recent Advances in Concrete Technology, Bucharest, Romania, June 2003; Volume 1, pp. 451-464.

5. Papayianni, I.; Anastasiou, E. Production of high-strength concrete using high volume of industrial by-products. Constr. Build. Mater. 2010, 24, 1412-1417. [CrossRef]

6. Shi, C.; Day, R.L. Early strength development and hydration of alkali-activated blast furnace slag/fly ash blends. Adv. Cem. Res. 1999, 11, 189-196. [CrossRef]

7. Sun, S. Investigations on steel slag cements. In Collections of Achievements on the Treatment and Applications of Metallurgical Industrial Wastes; Chinese Metallurgical Industry Press: Beijing, China, 1983; pp. 1-71.

8. Tang, M. An Investigation on Mineral Composition of Steel Slag for Cement Production; Research Report; Nanjing Institute of Chemical Technology: Nanjing, China, 1973.

9. Emery, J.J. Slag utilization in pavement construction. In Extending Aggregate Resources; ASTM International: West Conshohocken, PA, USA, 1982.

10. Wang, G.; Wang, Y.; Gao, Z. Use of steel slag as a granular material: Volume expansion prediction and usability criteria. J. Hazard. Mater. 2010, 184, 555-560. [CrossRef] [PubMed]

11. Mozt, H.; Geiseler, J. Products of steel slags. In Proceedings of the International Conference on the Science and Engineering of Recycling for Environmental Protection, WASCON 2000, Harrogate, UK, 31 May-2 June 2000; pp. $207-220$.

12. Rojas, M.F.; Sánchez De Rojas, M.I. Chemical assessment of the electric arc furnace slag as construction material: Expansive compounds. Cem. Concr. Res. 2004, 34, 1881-1888. [CrossRef]

13. Pellegrino, C.; Gaddo, V. Mechanical and durability characteristics of concrete containing EAF slag as aggregate. Cem. Concr. Compos. 2009, 31, 663-671. [CrossRef] 
14. Gieseler, J.; Schlosser, R. Investigation concerning the structure and properties of steel slags. In Proceedings of the 3rd International Conference on Molten Slags and Fluxes, Glasgow, Scotland, 27-29 June 1988.

15. Kaewmanee, K.; Krammart, P.; Sumranwanich, T.; Choktaweekarn, P.; Tangtermsirikul, S. Effect of free lime content on properties of cement-fly ash mixtures. Constr. Build. Mater. 2013, 38, 829-836. [CrossRef]

16. Suito, H.; Yokomaku, T.; Hayashida, Y.; Takahashi, Y. Effect of free lime on disintegration of LD slags. Tetsu-to-Hagané 1977, 63, 2316-2325. [CrossRef]

17. Nawaz, A.; Julnipitawong, P.; Krammart, P.; Tangtermsirikul, S. Effect and limitation of free lime content in cement-fly ash mixtures. Constr. Build. Mater. 2016, 102, 515-530. [CrossRef]

18. Tsimas, S.; Moutsatsou-Tsima, A. High-calcium fly ash as the fourth constituent in concrete: Problems, solutions and perspectives. Cem. Concr. Compos. 2005, 27, 231-237. [CrossRef]

19. Hassibi, M. An Overview of Lime Slaking and Factors that Affect the Process. In Proceedings of the 3rd International Sorbalit Symposium, New Orleans, LA, USA, 3-5 November 1999; pp. 2-20.

20. Gao, P.W.; Xu, S.Y.; Chen, X.; Li, J.; Lu, X.L. Research on autogenous volume deformation of concrete with MgO. Constr. Build. Mater. 2013, 40, 998-1001. [CrossRef]

21. Boynton, R.S. Chemistry and Technology of Lime and Limestone; Wiley: New York, NY, USA, 1980.

22. Boldyrev, V.V. Reactivity of solids: Past, present and future. J. Therm. Anal. 1993, 40, 1041-1062. [CrossRef]

23. Kneller, W.A.; Gupta, J.; Borkowski, M.L.; Dollimore, D. Determination of original free lime content of weathered iron and steel slags by thermogravimetric analysis. Transp. Res. Rec. 1994, 1434. Available online: https://trid.trb.org/view/409659 (accessed on 1 November 2021).

24. ASTM International. C114-18 Standard Test Methods for Chemical Analysis of Hydraulic Cement; ASTM International: West Conshohocken, PA, USA, 2018.

25. European Standard. EN 450 Fly Ash for Concrete-Definitions, Requirement and Quality Control; European Standard: Brussels, Belgium, 1994.

26. ASTM International. C151/C151M-18 Standard Test Method for Autoclave Expansion of Hydraulic Cement; ASTM International: West Conshohocken, PA, USA, 2018.

27. Wang, X.Y.; Xue, Z.L.; Li, J.L. Investigation of the reactivity and grain size of lime calcined at extra-high temperatures by flash heating. J. South. African Inst. Min. Metall. 2016, 116, 1159-1164. [CrossRef]

28. Berent, K.; Komarek, S.; Lach, R.; Pyda, W. The Effect of Calcination Temperature on the Structure and Performance of Nanocrystalline Mayenite Powders. Materials 2019, 12, 3476. [CrossRef] [PubMed]

29. Mohamad, S.F.S.; Mohamad, S.; Jemaat, Z. Study of calcination condition on decomposition of calcium carbonate in waste cockle shell to calcium oxide using thermal gravimetric analysis. ARPN J. Eng. Appl. Sci. 2016, 11, 9917-9921.

30. $\mathrm{Mu}, \mathrm{S}$.B.; Sun, Z.Y.; Su, X.P. A study on the microstructure and expanding mechanism of highly free-calcium oxide cements. $J$ Wuhan Univ. Technol. 2001, 23, 27-30.

31. Deng, M.; Hong, D.; Lan, X.; Tang, M. Mechanism of expansion in hardened cement pastes with hard-burnt free lime. Cem. Concr. Res. 1995, 25, 440-448. [CrossRef]

32. Halder, B.; Tandon, V.; Tarquin, A.; Ramana, C. Influence of coal fly ash on mechanical properties of mortar consisting of total dissolved solids. In Proceedings of the World of Coal Ash Conference, Lexington, KY, USA, 21-24 October 2009; pp. $22-25$.

33. Wang, Q.; Wang, D.; Zhuang, S. The soundness of steel slag with different free $\mathrm{CaO}$ and $\mathrm{MgO}$ contents. Constr. Build. Mater. 2017, 151, 138-146. [CrossRef] 